Jpn. J. Oral Biol., $30: 683-690,1988$.

\title{
ORIGINAL
}

\section{A computer system for measurement of neural activity in the cerebral cortex}

\author{
Kosei Taira and Takashi Suzuki \\ Department of Oral Physiology, School of Dentistry, Iwate \\ Medical University, Morioka, Iwate 020, Japan \\ [Accepted for publication: February 22, 1988]
}

Key words : Computer system/microdrive/ neural activity / image processing/cerebral cortex

\begin{abstract}
This paper describes a newly designed measurement system which drives a recording electrode and analyzes the neural activity in the cerebral cortex. The system is composed of two main parts. One part, for electrode positioning, is to control the recording electrode in three-dimensions, and the other part, for data collection and processing, is to perform the signal processing of neural potentials into a digital format, the storage of experimental data, and its mathematical analysis. The system was designed to analyze slow wave-form activity such as evoked potentials and electroencephalograms (EEG). The measurement system was utilized in the experiments to record the distribution of evoked potentials in the somatosensory cortical oral area of the cat, and it was able to position the recording electrode accurately in the cerebral cortex and to reduce the time for the experiment and data processing to less than $1 / 10$.
\end{abstract}

\section{Introduction}

Digital computer systems have been employed in the field of electrophysiological studies of the central nervous system for the purposes of mathematical analysis of such neural activities as impulse discharges ${ }^{1-5)}$, evoked potentials $^{6,7)}$, and electroencephalograms (EEG) ${ }^{8,9)}$. The properties of these neural activities and the information processing in the nervous system have been quantitatively analyzed by a computer system, regulating the parameters of peripheral stimulation applied to experimental subjects ${ }^{10}$. As the neurophysiological studies progressed, some devices were developed to record stably single-unit activity for 2-3 hours by penetrating a microelectrode into the cerebral cortex ${ }^{11-13}$. The structures and functions of the cerebral cortex, for example, the columnar organizations ${ }^{14,15)}$, were clarified by these devices.

In the present study, a computer-based measurement system was developed, in which a microelectrode can be driven particularly along the $\mathrm{X}, \mathrm{Y}$, and $\mathrm{Z}$ axes with a high accura- cy, and the neural activity can be recorded stably enabling the analysis of neural circuits in the cerebral cortex. In this paper, the organization and control process of the measurement system are described. The measurement system was used for the analysis of the evoked potential distributions on the somatosensory cortical oral area ${ }^{16)}$ after applying mechanical stimulation to the canine teeth of the cat $^{5,17)}$. The potential distributions and their time courses on the cerebral cortex were shown on a color display as video images.

Design and organization of the measurement system

In the measurement system, the part for three-dimensional positioning of the electrode was composed of a microdrive, stepping motors, and an automatic positioning controller (APC) (Fig. 1A). The part for data collection consisted of a preamplifier, a memoryunit (SIGNAL PROCESSOR; 7T-07A, Sanei) containing an analogue to digital (A-D) converter, a microcomputer, a CRT display, and a keyboard. The part for data pro- 


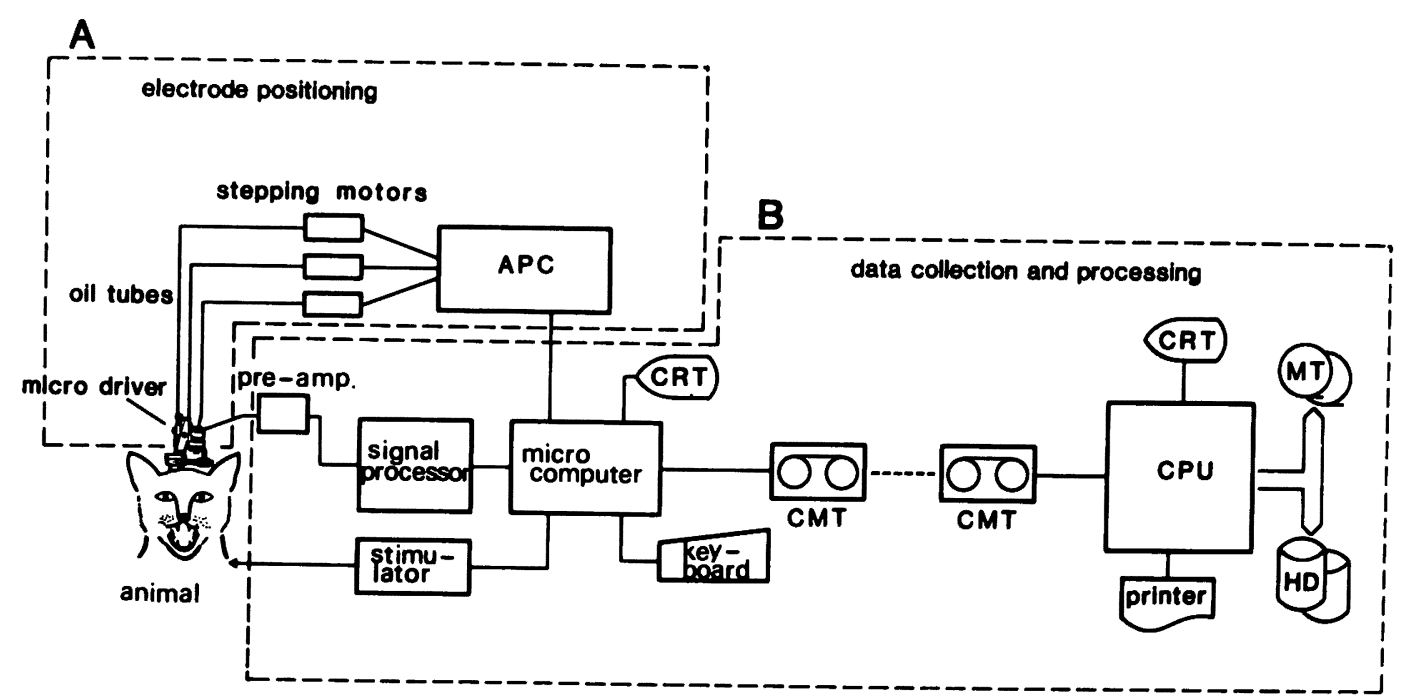

Fig. 1 Block diagram of the measurement system. A. The part of the system for the electrode positioning. B. The part of the system for data collection and data processing. The microcomputer shown in B transfers neural data to the cassette magnetic tape unit (CMT), gives the instruction codes to the automatic positioning controller (APC), and send the onset signals to the stimulator. A general purpose minicomputer system is illustrated on the right in $\mathrm{B}$.

cessing consisted of a minicomputer system (OKITAC 50/40) : two magnetic tape drive units (MT), a hard disk unit (HD, 84M bytes), a CRT, a printer, and a central processing unit (CPU, main memory: $64 \mathrm{~K}$ words, 1 word $=16$ bits) (Fig. 1B). A cassette magnetic tape (CMT) was used as the connecting medium between the instruments for data collection and ones for data processing because of its portability and low cost. According to commands from the keyboard, a recording electrode was automatically positioned in the target areas and the neural activity in the cerebral cortex was recorded under the control of the computer programs. The neuralactivity data and the parameters of the experimental conditions were stored on the CMT via the SIGNAL PROCESSOR and microcomputer. After the experiment was finished, the data on the CMT were transferred to the MT or HD of the minicomputer system. The results of the data analysis were displayed on the CRT or the printer.

\section{Control process of the microdrive}

The remote control of the microdrive was accomplished via polyethylene tubes by shifting the hydraulic cylinders which were attached to three stepping motors. According to commands from the keyboard, rotation of these stepping motors was regulated by the microprocessor-based, automatic positional controller (APC). The repeatability of the electrode positioning (control accuracy) was approximately $20 \mu \mathrm{m}$ on the X-Y plane and 5 $\mu \mathrm{m}$ along the $\mathrm{Z}$ axis. In this system, two types of electrode manipulations, a random access mode and a sequential access mode, were prepared. The former was a control process to locate the electrode tip at a target point, $P(x, y, z)$, in order to examine the characteristics of neural activities by trial and error for some stimulus parameters (Fig. 2A). The latter was an automatic control process to move and set the electrode sequentially in lattice planes to measure the potential distributions in the cerebral cortex for the stimulus parameters assigned in advance (Fig. 2B). In the latter mode, the numbers of electrode positions $X_{i}, Y_{j}, Z_{k}$, and the lattice distances $\Delta \mathrm{x}, \Delta \mathrm{y}$, and $\Delta \mathrm{z}$ were selected by keyboard operations. As soon as the electrode tip was positioned at a target point, the data of its location were returned from the APC to the microcomputer and shown on the CRT. While the APC controlled the microdrive, the microcomputer processed the neural data 


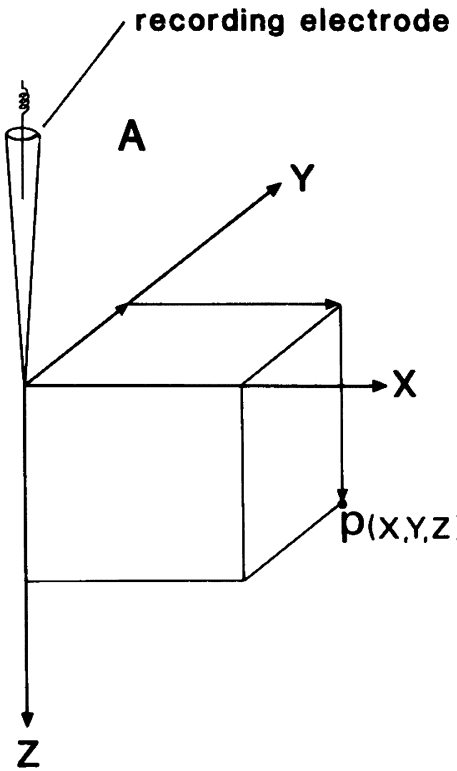

random access mode

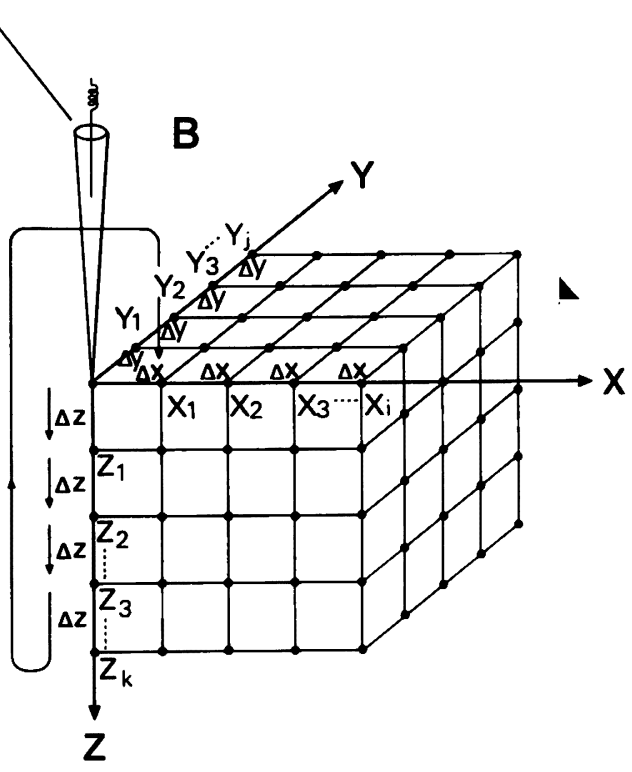

sequential access mode

Fig. 2 Two modes of electrode positioning. A. Random access mode in which the commands can determine the target point, $\mathrm{P}(\mathrm{x}, \mathrm{y}, \mathrm{z})$, of an electrode tip in the cerebral cortex. B. Sequential access mode in which the commands regulate the numbers of points of electrode positions, $\mathrm{X}_{\mathrm{i}}, \mathrm{Y}_{\mathrm{j}}, \mathrm{Z}_{\mathrm{k}}$, and interval distances $\Delta \mathrm{x}, \Delta \mathrm{y}, \Delta \mathrm{z}$ along the $\mathrm{X}, \mathrm{Y}$, and $\mathrm{Z}$ axis, respectively.

which were transferred from the SIGNAL PROCESSOR.

In order to prevent accidental injury to the cerebral cortex due to operator's error, the computer was programmed so as to allow the electrode to move along the $\mathrm{X}$ and $\mathrm{Y}$ axes only after leaving the cerebral cortex. Furthermore, limit switches were attached to each shaft of the stepping motors to prevent an excessive rotation due to program errors or unexpected power surges.

Data collection and processing

Neural signals recorded by the electrode were fed via preamplifier to the SIGNAL PROCESSOR in which A-D conversion of the neural signals were performed (sampling time intervals, $100 \mu \mathrm{s}-1 \mathrm{~s})$. The data in the SIGNAL PROCESSOR (or in the CMT) consisted of the information on experimental conditions (256 words) and on neural signals ( $4 \mathrm{k}$ words). Fig. 3 shows the detailed data format in the CMT. The figure on the right indicates the header label for the experimental conditions which correspond to the LABEL partition on the left. In this label, block $\mathrm{A}$ is the division for the serial num. ber of the experiment, the animal's body weight, and sex. Block $B$ is the division for the data on the electrode positions and the stimulus parameters such as stimulus magnitude, duration, velocity, and direction. Block $C$ is the division for the conditions of the A-D conversion chosen on the control panel of the SIGNAL PROCESSOR. As shown at the left of the figure, the data of the neural signals, DATA (1), DATA (2), - - DATA $(\mathrm{N})$, in which the individual data-length was $4000 / \mathrm{N}$ words $(\mathrm{N}=1,2,4,8,16)$, follow the header label. One hundred and twenty five sets of header labels and the data on neural signals could be stored in a single CMT. The data transferred to the general purpose computer system (Fig. 1, right side) were analyzed with statistical methods such as auto-correlation, cross-correlation, timeand ensemble-average, and spectral analysis.

Practical estimation of the measurement system

To estimate the utility in practical application of the above-described measurement sys- 


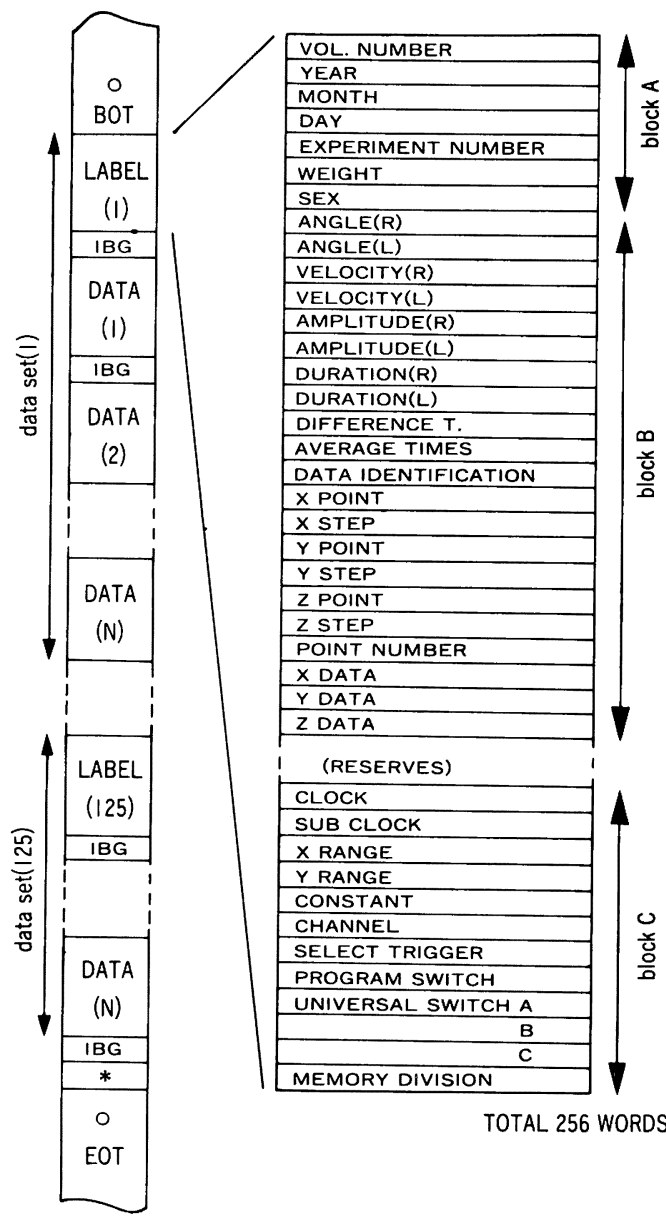

Fig. 3 Data format on the cassette magnetic tape. A header label (LABEL) indicating experimental conditions, and a group of neural data (DATA (1), DATA (2), - D DATA $(\mathrm{N})$ ) are stored in pairs on the magnetic tape. The figure on the right shows the detailed format of the header label. BOT., begin of tape, EOT., end of tape, IBG., inter block gap.

tem, the distributions of evoked potentials on the somatosensory cortical oral area of the cat $^{5,16)}$ were analyzed. Trapezoid wave-form mechanical stimulations were applied to the right upper canine tooth ${ }^{17)}$, and evoked potentials were recorded in the depth ( $Z$ axis, Fig. 4) or in a grid of 320 points (X-Y plane, Fig. 5A) on the focal site of the anterior coronal gyrus by positioning a glass-enclosed silver electrode in $200 \mu \mathrm{m}$ steps. Evoked potentials obtained on the surface of the somato-

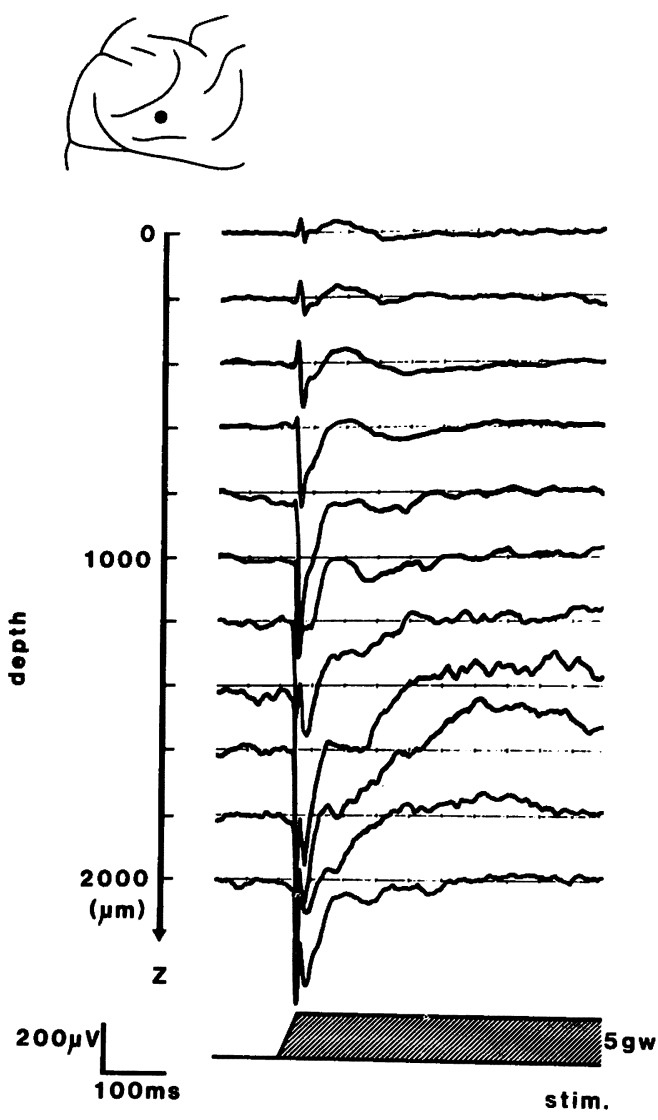

Fig. 4 Application of the measurement system. Depth recording of evoked potentials was performed by $200 \mu \mathrm{m}$ steps in the somatosensory cortical oral area after mechanical stimulation of the upper right canine tooth of the cat. The traces starts $100 \mathrm{~ms}$ before the stimulus onset. Thu upper inset shows the left cortical hemisphere. A solid circle indicates the electrode penetration point. The lower insets show the stimulus wave-form and the calibrations for the potential wave-forms.

sensory cortex consisted of a primary positive-negative deflection and a secondary positive deflection (Fig. 5A). The primary deflection inverted the polarity in the depth recording (Fig. 4).

The evoked potential data at each grid-point were transformed into color images by the data processing part of the computer system in the following manner. The amplitude of these potentials (maximum value $\pm 400 \mu \mathrm{V}$ ) was graded into eight classes in $100 \mu \mathrm{V}$ steps, 


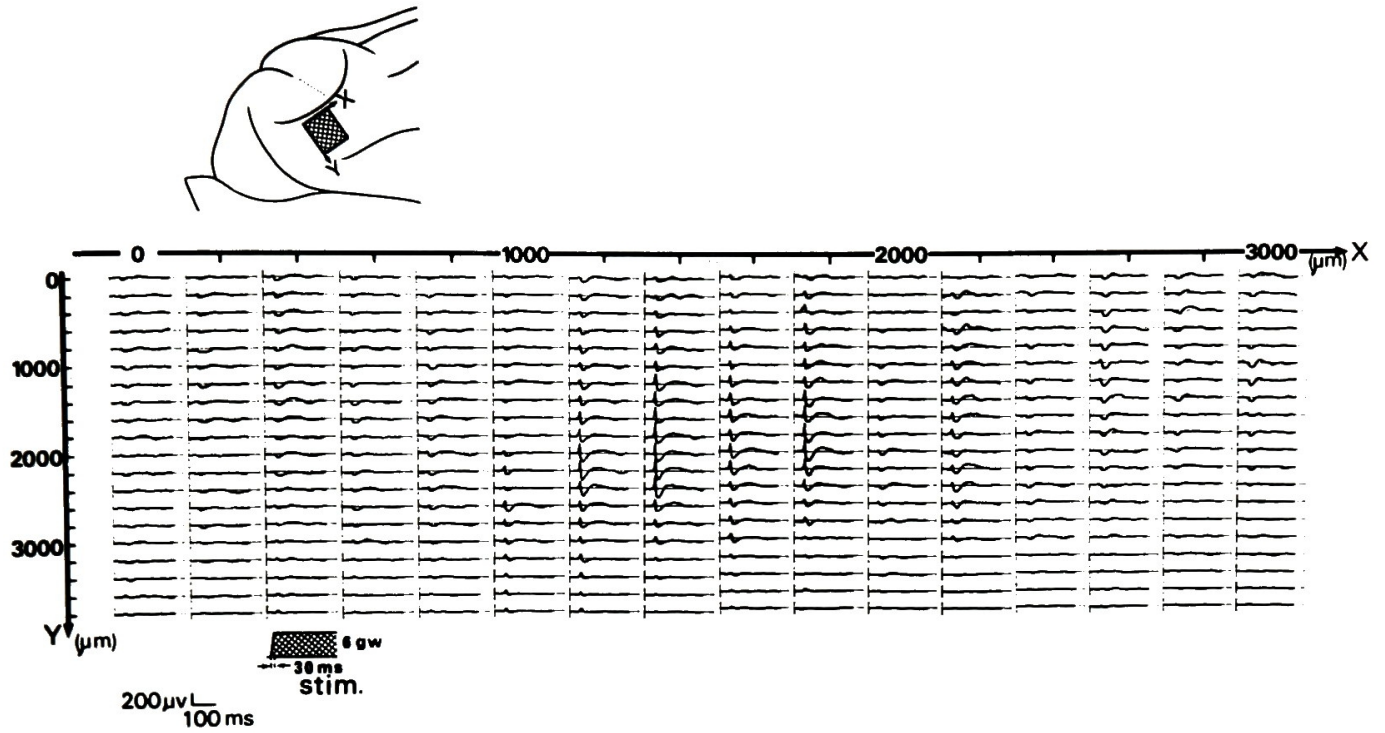

Fig. 5A Distribution of evoked potentials on the surface of the somatosensory cortex after mechanical stimulation of the upper right canine tooth. The traces starts $30 \mathrm{~ms}$ before the stimulus onset. The recording points were moved along the $\mathrm{X}$ or $\mathrm{Y}$ axis by $200 \mu \mathrm{m}$ steps. The evplored area is shaded in the upper inset.

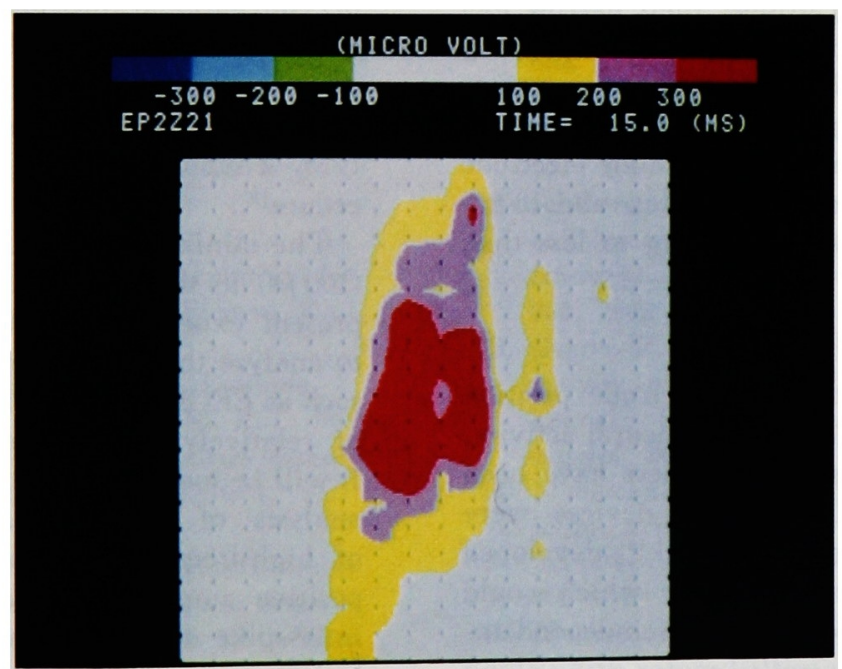

Fig. 5B Color image of the potential distribution at $15.0 \mathrm{~ms}$ after the onset of stimulation. The material used in this figure was the same as in Fig. $5 \mathrm{~A}$. The top of figure shows the relation between the potential amplitude and its color gradation.

and one of eight colors from red $(+300 \mu \mathrm{V}-$ $+400 \mu \mathrm{V})$ to blue $(-300 \mu \mathrm{V}--400 \mu \mathrm{V})$ was assigned to each class of potential amplitude. Finally, the potential distribution over the grid-points on the cortical surface, which changed every moment, was shown on the color display. Figs. $5 \mathrm{~B}$ and $5 \mathrm{C}$ are the color images of the contour map of the potential distributions plotted in Fig. 5A at $15.0 \mathrm{~ms}$ and at $20.0 \mathrm{~ms}$ after the onset of mechanical stimulation, respectively. In Fig. 5B, the focus of positive potentials (red) is seen at the center 


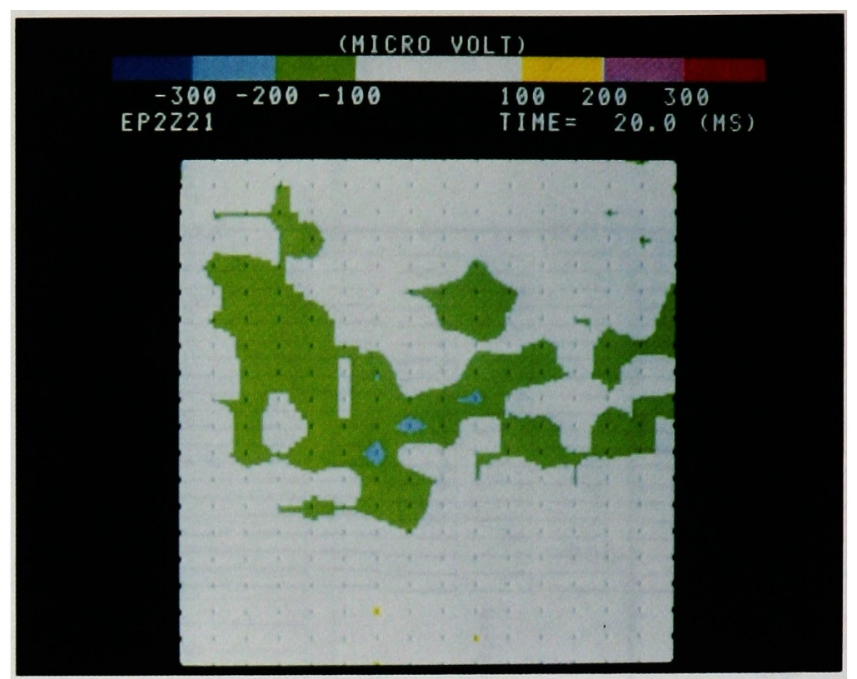

Fig. 5 C Color image of the potential distribution in Fig. $5 \mathrm{~A}$ at $20.0 \mathrm{~ms}$ after the on set of stimulation.

cooresponding to the primary positive deflections in Fig. 5A. On the other hand, in Fig. $5 \mathrm{C}$, though the distribution of the negative potentials are rather diffuse, their narrow foci (blue) are observed in the area overlapping the main focus of the primary positive potentials. Applying our measurement system, it was able to position the recording electrode accurately in the cerebral cortex and to reduce the time for data processing to less than $1 / 10$.

\section{Discussion}

In order to control the electrode position accurately and to record stably neural activity, several types of cortical chambers have been developed $^{11-13)}$. All of those devices were manually controlled. Reitboeck ${ }^{18)}$ developed an electrode recording device which could position 19 fiber-microelectrodes independently by a computer-controlled motor drive along the vertical axis. His device had an advantage of being able to record simultaneously multi-unit activity in the cerebral cortex, although the minimum amount of displacement of positioning the electrodes on the horizontal plane was limited by the diameter of each fiber-electrode $(120 \mu \mathrm{m})$.

With the microdrive system described in this paper, the electrode positioning was performed both on the vertical and horizontal planes under computer control. The accuracy in driving an electrode, particularly on the horizontal plane, was higher than that of conventional instruments ${ }^{11-13)}$. However, if an intracellular recording is intended using this system, it will probably be necessary to control the electrode positions more accurately by a supplementary feedback control procedure $^{19)}$.

The minimum value of the sampling clock $(100 \mu \mathrm{s})$ in the A-D converter as used in the present experiment seemed sufficiently small to analyze the wave-forms of neural activities such as EEGs and evoked potentials consisting of relatively low frequency components ${ }^{9,201}$. It will be too large for the frequency-domain analysis of impulse wave-forms consisting of high-frequency components ${ }^{21)}$. However, positive amplitude, negative amplitude, and inter-spike time intervals of the multi-unit activity can be converted to digital signals by the programming of SIGNAL PROCESSOR. Therefore, the time series analysis of the impulse discharges ${ }^{22-251}$ is able to perform in the present measurement system. Detailed descriptions of the time series analysis of the impulse discharges will be reported in another paper.

Our measurement system will be a useful tool for analyzing the behavior of complicated, three-dimensional neural circuits such as the 
cerebral cortex and can be applied also to the other acts of the central nervous system.

\section{Acknowledgements}

The authors had the assistance of Prof. R. Yokoyama, Mr. Y. W atanabe and Mr. O. Kanno of Iwate University, who contributed their experimental skill, sustained effort, and grasp of objec- tives to the accomplishment of the experimentalprogram. We wish to thank Drs. K. Okuda and $T$. Sato for helpful advice and critical reading of the manuscript. This study was supported in part by Grant-in-Aid 577728 for Scientific Research from the Ministry of Education, Science, and Culture of Japan.

抄録：大脳皮質のニューロン活動を記録し，その特性を解析する目的で，コンピュータを利用した動物実 験計測システムを開発した。システムは，三次元油圧駆動チャンバ，ステップモータ，電極位置決め装置か ら成る記録電極制御部と, 前置増幅器, CRT, シグナルプロセッサ, マイクロコンピュータ, 汎用ミニコン ピュータから成るデータ収集，解析部から構成される。本システムによって，脳内での記録電極の位置制 御, 誘発電位や脳波などのニューロン活動の記録と解析, そして動物実験に伴う一連の操作の自動化が可能 になった。本研究では特に，ネコの犬歯の機械的刺激に対する誘発電位を大脳皮質口腔領域上の 320 点で記録 し, それらのデータの画像解析を行った。その結果, 実験操作とデータ解析に費す時間が $1 / 10$ 以下に短縮 され：かつデータ解析精度が改善されることが明らかになった。

\section{References}

1) Rodieck, R. W., Kiang, N. Y. -S. and Gerstein, G. L. : Some quantitative methods for the study of spontaneous activity of single neurons. Biophysical. J. $2: 351-368$, 1962.

2) Rhode, W. S. and Soni, V.: Neural unit data analysis system. J. Cybern. 5 : 107-120, 1975.

3) Harding, G. W. and Towe, A. L.: An automated on-line, real-time laboratory for single neuron studies. Comput. Biomed. Res. 9 : 471-501, 1976.

4) Gerstein, G. L., Bloom, M. J., Espinosa, I. E., Evanczuk, S. and Turner, M. R.: Design of a laboratory for multineuron studies. IEEE Trans. Systems Mann Cybern. SCM-13 : 668-676, 1983.

5) Taira, K.: Characteristics of periodontal mechanosensitive neurons in the first somatosensory cortex of the cat. Brain Res. 409 : 52-61, 1987.

6) Aunon, J. I. : Computer techniques for the processing of evoked potentials. Comput. programs Biomed. 8 : 234-255, 1978.

7) Cohen, B. A. and Myklebust, J. : Evoked potential measurement and analysis on a small laboratory computer. Comput. programs Biomed. 8 : 256-261, 1978

8) Gevins, A. S. : Pattern recognition of human brain electrical potentials. IEEE trans. Pattern Analy. Machine Intel. PAMI-2 : 383-404, 1980.
9) Nunez, P. L. : Electric Fields of the Brain, Oxford Univ. Press, New York, pp484, 1981.

10) Brown, P. B. : Computer Technology in Neuroscience, Hemisphere, W ashington, pp. 650, 1976.

11) Davies, P. W.: Chamber for microelectrode studies in the cerebral cortex. Science 142: 179-180, 1956.

12) Jernberg, N. and Brooks, V. B. : A differential screw drive for microelectrodes. Electroencephalogr. Clin. Neurophysiol. 14 : 931933, 1962.

13) Evarts, E. V.: A technique for recording activity of subcortical neurons in moving animals. Electroencephalogr. Clin. Neurophysiol. 24 : 83-86, 1968.

14) Mountcastle, V. B. : Modality and topograph ic properties of single neurons of cat's somatic sensory cortex. J. Neurophysiol. 20 : 408-434, 1957.

15) Mountcastle, V. B. : Cortical organization and the group-selective theory of higher brain function. In G.M. Edelman and V.B. Mountcastle (Eds.), The Mindful Brain, MIT Press, Massaschusetts, pp. 7-50, 1978.

16) Taira, K.: The representation of the oral structures in the first somatosensory cortex of the cat. Brain Res. 409:41-51, 1987.

17) Taira, K.: A vector stimulator for neurophysiological studies of periodontal mechanosensitive units. J. Neuroscience Methods 23 : 43-48, 1988.

18) Reitboeck, H. J. P.: A 19-channel matrix 
drive with individually controllable fiber microelectrodes for neurophysiological applications. IEEE. Trans. Systems Man Cybern. SMC-13:676-683, 1983.

19) Truxall, J. G.: Automatic Feedback Control System Synthesis, McGraw-Hill, New York, 1955.

20) Eccles, J. C. : Interpretation of action potentials evoked in the cerebral cortex. Electroencephalogr. Clin. Neulophysiol. 3 : 449-464, 1951.

21) D'hollander, E.H. and Orban, G.A.: Spike recognition and on-line classification by unsupervised learning system. IEEE. Trans. Biomed. Eng. BME-26 : 279-284, 1979.
22) Moore, G. P., Perkel, D. H. and Segundo, J. P.: Statistical analysis and functional interpretation of neuronal spike data. Annu. Rev. Physiol. 28 : 493-522, 1966.

23) Perkel, D. H., Gerstein, G. L. and Moore, G. P. : Neuronal spike trains and stochastic point processes; I. The single spike train. Biophysical J. 7 : 391-418, 1967.

24) Perkel, D. H., Gerstein, G. L. and Moore, G. P. : Neuronal spike trains and stochastic point processes; II. Simultaneous spike trains. Biophysical J. $7:$ 419-440, 1967.

25) Perkel, D. H. and Bullock, T. H. : Neural coding. Neurosciences Res. Prog. Bull. 6 : 218-350, 1968. 